Reprod. Nutr. Dévelop., 1982, 22 (2), 427-438.

\title{
In vitro metabolism of progesterone and $17 \alpha$-hydroxyprogesterone in the testis of the rainbow trout, Salmo gairdneri Rich., at different stages of spermatogenesis
}

\author{
J. DÉPÊCHE, O. SIRE
}

\begin{abstract}
Université Pierre-et-Marie Curie,
Laboratoire de Physiologie de la Reproduction des Vertébrés,

4, place Jussieu, 75230 Paris Cedex 05, France.
\end{abstract}

Summary. Rainbow trout testicular fragments were incubated at 8 different stages of the spermatogenetic cycle in the presence of tritiated progesterone or $17 \alpha$-hydroxyprogesterone. This paper describes the potential enzymatic activities involved in the $\Delta_{4}$ route leading to the production of " major » derivatives.

1) A 5-reductase converted progesterone into $5 \alpha(\beta)$-pregnane-3,20-dione.

2) A $20 \beta$-oxydoreductase converted $17 \alpha$-hydroxyprogesterone into $17 \alpha$-hydroxy-20 $\beta$ dihydroprogesterone. At some stages this synthesis reached or exceeded androgen production.

3) $20 \beta$-oxydoreductase, $17-20$ desmolase and $17 \beta$-oxydoreductase are proposed as putative enzymatic steps in the regulation and modulation of steroidogenic metabolism in the trout testis.

4) The physiological role of the different major steroids synthesized by the testis in vitro is discussed, and the hypothesis of the involvement of $17 \alpha$-hydroxy-20 $\beta$-dihydroprogesterone in the control of germ cell mitotic activity and/or feedback on the hypothalamo-pituitary system is examined.

\section{Introduction.}

Steroid biosynthesis in the testis varies in different vertebrate species (Ozon, 1972 ; Kime, 1980). This diversity is expressed by differences in metabolic routes, types of steroids produced, and probably also in modalities of regulation, depending on the particular reproductive strategy. It is thus primordial to know the steroidogenic metabolism of a given species before trying to analyze the role of the steroids.

The steroidogenic function of the testis plays a complex role in controlling the initiation and progress of spermatogenesis. In fact, the various steroids produced act either locally or at many extra-gonadal sites, such as the hypothalamo-pituitary system, where they contribute to the modulation of gonadotropic secretion. 
The testis of teleost fish with an annual reproductive cycle seems a good model for analyzing the relationships between steroidogenic metabolism and the spermatogenetic process, including spermiogenesis and spermiation. The proliferation and differentiation of male germ cells spread over several months of the year (Billard et al., 1972 ; Drance et al., 1976 ; van den Hurk et al., 1978). Stages, corresponding to the progression of the front of the spermatogenetic wave, can be defined by the synchronous evolution of germ cells within the testicular cysts (Billard and Escaffre, 1975).

Potential enzymatic activities in the gonad can be identified by studying the in vitro metabolism of radioactive steroids, but none of the studies in teleosts (see review by Kime, 1980) has traced qualitative or quantitative modifications in metabolism during the cycle.

Due to the numerous metabolic routes operating in the gonad, the complete pattern of enzymatic activities cannot be determined when a single precursor is used. This paper reports results obtained with progesterone and $17 \alpha$-hydroxyprogesterone, two C21 steroids of the $\Delta_{4}$ synthesis route.

\section{Material and methods.}

Fish. - Three-year old male rainbow trout (Salmo gairdneri Rich.) in their second reproductive cycle were used. They were anesthetized by immersion in a bath of 0.05 p. 100 phenoxy-2-ethanol. Whole transversal sections, of about

TABLE 1

Stages of spermatogenesis in the rainbow trout

\begin{tabular}{|c|c|c|c|c|}
\hline Stage & $\begin{array}{l}\text { Correspondance } \\
\text { with S. fario } \\
\text { stages }\end{array}$ & $\begin{array}{l}\text { Definition (most } \\
\text { advanced stage } \\
\text { of spermatogenesis) }\end{array}$ & $\begin{array}{l}\text { GSI (1) } \\
\text { and no. } \\
\text { of fish }\end{array}$ & Month \\
\hline I & $\mathrm{I}_{1}$ & $\begin{array}{l}\text { A spermatogonia (and residual sperma- } \\
\text { tozoa) }\end{array}$ & $\begin{array}{c}0.3-0.9 \\
(6)\end{array}$ & $3-5$ \\
\hline II & II & $A$ and $B$ spermatogonia & $0.3-0.9$ & $4-6$ \\
\hline III a & III & $\begin{array}{l}\text { Meiotic prophase does not exceed the } \\
\text { zygotene stage }\end{array}$ & $\begin{array}{c}0.3-0.9 \\
(5)\end{array}$ & $5-6$ \\
\hline III b & & Spermatids & $\begin{array}{l}0.3-0.9 \\
(3)\end{array}$ & $6-7$ \\
\hline IV & IV & $\begin{array}{l}\text { Onset of spermiogenesis (few spermato- } \\
\text { zoa) }\end{array}$ & $\begin{array}{r}0.3-1 \\
(7)\end{array}$ & $6-7$ \\
\hline $\mathrm{V}$ & v & $\begin{array}{l}\text { End of spermatogenesis (many sperma- } \\
\text { tozoa) }\end{array}$ & $\begin{array}{l}1.5-2.5 \\
(6)\end{array}$ & $7-8$ \\
\hline VI-VII & $\begin{array}{l}\text { VI } \\
\text { VII }\end{array}$ & $\begin{array}{l}\text { Onset of spermiation (some spermatocytes } \\
\text { still present) }\end{array}$ & $\begin{array}{l}2.5-3.5 \\
(7)\end{array}$ & $9-11$ \\
\hline VIII & VIII & Advanced spermiation & $\begin{array}{l}3-4 \\
(3)\end{array}$ & $12-1$ \\
\hline
\end{tabular}

(1) GSI : testicular weight/fresh weight of intact fish $\times 100$. 
$100 \mathrm{mg}$ each from the middle of the testis, were cut in small pieces and washed in three successive baths of Eagle's medium (Eagle, 1959) before incubation with the radioactive precursor.

The stage of spermatogenesis was determined from the most advanced stage observed in several histological sections. We used a slightly modified version of the classification proposed by Billard and Escaffre (1975) for the fario trout (table 1).

Steroids. $-1,2,6,7-{ }^{3} \mathrm{H}$ progesterone (specific activity : $96 \mathrm{Ci} / \mathrm{mmol}$ ) and $17 \alpha$ hydroxy $-7(\mathrm{n})-{ }^{3} \mathrm{H}$ progesterone (specific activity : $10.7 \mathrm{Ci} / \mathrm{mmol}$ ) were furnished by the Radiochemical Centre (Amersham, UK). The non-radioactive steroid standards were provided by Sigma Chemical Co. $1.10^{6} \mathrm{dpm}$ of radioactive precursor was mixed with the non-radioactive steroid to obtain a final concentration of $5.10^{-7} \mathrm{M}$ (specific activity : $0.3 \mathrm{Ci} / \mathrm{mmol}$ ).

Incubations. - The fragments of testis were incubated for $3 \mathrm{~h}$ at $14{ }^{\circ} \mathrm{C}$ in $3 \mathrm{ml}$ of Eagle's medium in 15- $\mathrm{ml}$ vials which were shaken constantly. The medium was equilibrated with a gaseous mixture of 50 p. 100 nitrogen, 49 p. 100 oxygen and 1 p. $100 \mathrm{CO}_{2}$. In these conditions, the $\mathrm{pH}$ was about 7.9 which is the value of the coelomic medium (Jalabert, personal communication). The radioactive precursor was introduced at the beginning of the incubation which was carried out at a set time $(11 \mathrm{~h})$ to take into account the effect of possible circadian variations in metabolism. At the end of incubation, the fragments were blotted, then homogenized in the incubation medium. Into the homogenate, we introduced $50 \mu \mathrm{g}$ of various steroids used as carriers and $10000 \mathrm{dpm}$ of 4 tracers labelled with ${ }^{14} \mathrm{C}$ (testosterone, $5 \alpha$-dihydrotestosterone, estrone and $17 \beta$-estradiol).

Extraction. - The free steroids were extracted by ether $(3 \times 10 \mathrm{ml})$, and the homogenate was treated with 1300 Fishman units of $\beta$-glucuronidase at $37{ }^{\circ} \mathrm{C}$ for $48 \mathrm{~h}$. The glucuroconjugated steroids were then extracted by adding $2 \times 10 \mathrm{ml}$ of ether.

Separation and identification of steroids. - The steroids were separated by thin-layer chromatography on Merck silica gel $(60 \mathrm{~F} \mathrm{254)}$ in the presence of steroid standards. The extracts were first chromatographed in the chloroform/ethanol system $(95 / 5 ; \mathrm{v} / \mathrm{v})$; the steroids were identified in the presence of authentic steroids after chromatography in different systems : (i) chloroform/ethyl acetate $5 / 1$, (ii) chloroform/ethanol $95 / 5$, (iii) chloroform/acetone $9 / 1$, (iv) chloroform/ methanol/water $188 / 12 / 1$, (v) chloroform/ethyl acetate/methanol $45 / 45 / 10$, (vi) ethyl acetate/hexane/acetic acid/ethanol 72/13.5/10/4.5, (vii) benzene/ethanol 90/10, (viii) chloroform/ethyl acetate 1/1, (ix) chloroform/methanol 96/4, (x) cyclohexane/isopropanol 70/30, (xi) hexane/ethyl acetate 75/25, (xii)

Common designation and systematic nomenclature of the steroids cited: progesterone : 4-pregnene-3,20-dione; $5 \alpha(\beta)$-pregnane dione: $5 \alpha(\beta)$-pregnane-3,20-dione ; 17 $\alpha$-hydroxyprogesterone : $17 \alpha$-hydroxy-4-pregnene-3,20 dione ; $17 \alpha$-hydroxy-20 $\beta$-dihydroprogesterone : $17 \alpha, 20 \beta$-dihydroxy-4pregnen-3-one ; androstenedione : 4-androstene-3,17-dione ; 11 1 -hydroxy-androstenedione : $11 \beta$ hydroxy-4-androstene-3,17-dione ; testosterone : 17 $\beta$-hydroxy-4-androsten-3-one ; $11 \beta$-hydroxytestosterone : $11 \beta, 17 \beta$-dihydroxy-4-androsten-3-one ; 11-ketotestosterone : 4-androstene-3,11,17-trione ; cortisol : $11 \beta, 17 \alpha, 21$-trihydroxy-4-pregnene-3,20-dione. 
chloroform/ethanol 90/10. A steroid was identified by its isopolarity with the authentic steroid in at least two of the following chromatographic systems :

\section{Steroid :}

$5 \alpha(\beta)$-pregnane-3,20-dione

$17 \alpha$-hydroxyprogesterone

$17 \alpha$-hydroxy-20ß-dihydroprogesterone androstenedione

$11 \beta$-hydroxyandrostenedione testosterone

$11 \beta$-hydroxytestosterone

adrenosterone

11-ketotestosterone

cortisol

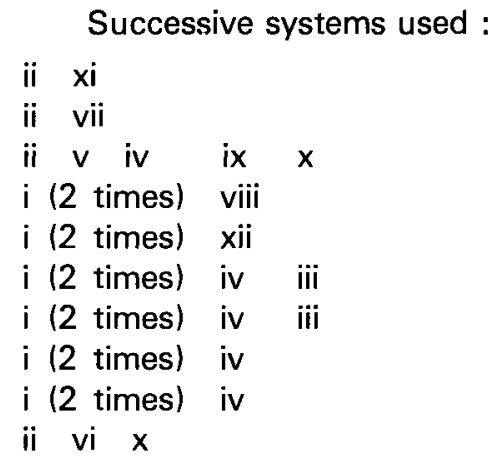

The usual reactions of oxidation, reduction and acetylation were initiated by methods described elsewhere (Sire and Dépêche, 1981). In particular, 17 hydroxy-20 $\beta$-dihydroprogesterone was acetylated by a mixture acetic anhydridepyridine $\left(12 \mathrm{~h}\right.$ at $\left.20^{\circ} \mathrm{C}\right)$ and the acetates were subsequently hydrolyzed by 5 p. $100 \mathrm{KOH}\left(1 \mathrm{~h}\right.$ at $\left.60^{\circ} \mathrm{C}\right)$. The 17 -hydroxy group was oxidized with chromic acid in the dark for $1 \mathrm{~h}$.

The derivatives were analyzed by chromatography in the presence of authentic derivatives.

The chromatograms were analyzed with a scanning radiochromatograph (Panax xy) at a speed of 120 or $600 \mathrm{~mm} / \mathrm{h}$.

Measurement of radioactivity. - After each steroid was eluted, an aliquot fraction $(1 / 10: 100 \mu \mathrm{l})$ was put into $15 \mathrm{ml}$ of a $\mathrm{PPO} / \mathrm{POPOP} /$ toluene mixture. Radioactivity was measured by double labelling in a liquid scintillation spectrometer equipped with an external standard (Packard Tricarb 3320). Extraction percentages were calculated from aliquot fractions $(20 \mu \mathrm{l})$ of the homogenate whose radioactivity was counted in a mixture of PPO/POPOP/toluene/Triton X 100.

Expression of results. - The amount of radioactivity found in each derivative formed was compared to the total radioactivity of the synthesized derivatives, using the formula :

$$
\text { steroid } S(p .100)=\frac{d p m \text { of steroid } S}{\text { total } d p m \text { recovered }- \text { precursor } d p m} \times 100 .
$$

The amount of precursor metabolization by the testis was expressed by the " percentage of metabolization " :

$\mathrm{dpm}$ of the whole of the derivatives

total $\mathrm{dpm}$ recovered $\times \mathrm{mg}$ of incubated fragment fresh weight

We used only those steroids ( " major » metabolites) representing more than 1 p. 100 of the total radioactivity. 


\section{Results.}

1) Metabolization rate. - The percentage of metabolization of both precursors was based on three incubations at different stages of the cycle (table 2). Progesterone metabolization ranged between 11 and 23 p. 100, whatever the stage of the cycle, except at stage VIII when it rose sharply to $70 \mathrm{p}$. 100 . The percentage of $17 \alpha$-hydroxyprogesterone metabolization was higher (40-50 p. 100) than that of progesterone. It exceeded 50 p. 100 at stages III a, III b and IV.

TABLE 2

Percentage of precursor metabolization at different stages of the cycle (means of 3 incubations)

\begin{tabular}{|c|c|c|c|c|c|c|c|c|}
\hline \multirow{2}{*}{ Precursor } & \multicolumn{8}{|c|}{ Stage } \\
\hline & 1 & II & III a & III b & IV & v & VI-VII & VIII \\
\hline $\begin{array}{l}\text { Progesterone } \ldots \ldots \ldots \ldots \\
17 \alpha \text {-Hydroxyprogesterone }\end{array}$ & $\begin{array}{l}12 \\
45\end{array}$ & $\begin{array}{l}23 \\
30\end{array}$ & $\begin{array}{l}11 \\
53\end{array}$ & $\begin{array}{l}11 \\
50\end{array}$ & $\begin{array}{l}15 \\
59\end{array}$ & $\begin{array}{l}11 \\
28\end{array}$ & $\begin{array}{l}20 \\
30\end{array}$ & $\underline{68}$ \\
\hline
\end{tabular}

2) Steroid g/ucuroconjugation. - The total estimation of the percentage of glucuroconjugated steroids was based on three incubations at different stages of the cycle (table 3). In our experimental conditions, it seemed to be low, never exceeding 3 p. 100.

\section{TABLE 3}

Percentage of total glucuroconjugated steroids (means of 3 incubations)

\begin{tabular}{|c|c|c|c|c|c|c|c|}
\hline \multirow{2}{*}{ Precursor } & \multicolumn{7}{|c|}{ Stage } \\
\hline & 1 & II & III a & III b & IV & V & VI-VII \\
\hline $\begin{array}{l}\text { Progesterone ........... } \\
17 \alpha \text {-Hydroxyprogesterone }\end{array}$ & $\begin{array}{l}0.9 \\
<1\end{array}$ & $\begin{array}{l}<1 \\
<1\end{array}$ & $\begin{array}{l}0.4 \\
<1\end{array}$ & $\begin{array}{l}0.5 \\
0.4\end{array}$ & $\begin{array}{l}0.5 \\
1.0\end{array}$ & $\begin{array}{l}3.0 \\
1.0\end{array}$ & $\begin{array}{l}2.0 \\
0.2\end{array}$ \\
\hline
\end{tabular}

3) In vitro metabolism of progesterone (table 4).

a) C21 steroids. - After chromatography in systems (ii) and (xi), we identified a derivative as being $5 \alpha(\beta)$-pregnane-3,20-dione; this derivative represented $14-23$ p. 100 of the radioactivity recovered in the derivatives at stages I to III a and 5-10 p. 100 recovered at more advanced stages (IV or more). At stage VIII, the percentage recovered was less than the detection threshold. 
TABLE 4

In vitro metabolism of progesterone (in p. 100 of the whole of the derivatives)

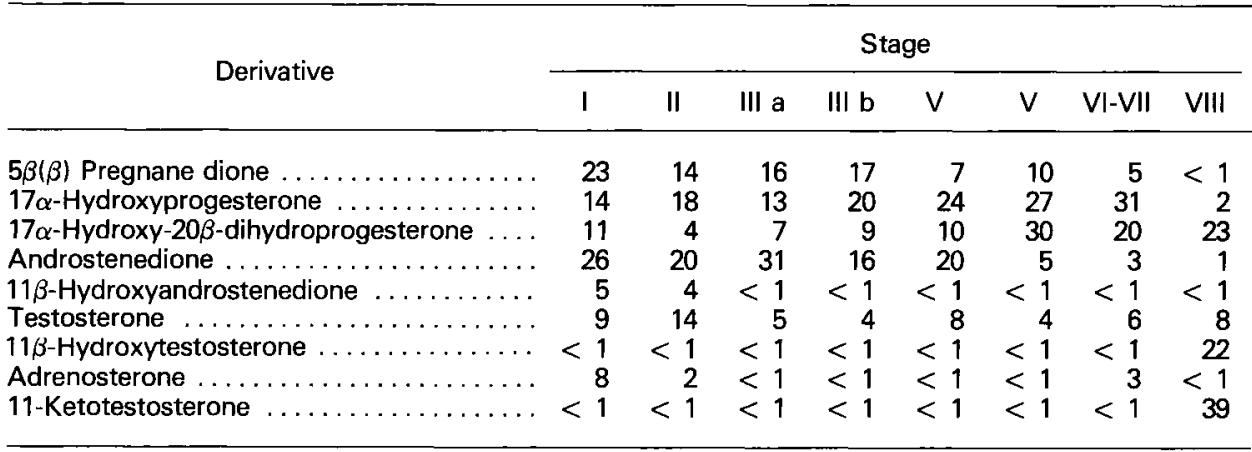

$17 \alpha-$ Hydroxyprogesterone was found at all stages ; between 14 and 31 p. 100 were recovered during the cycle, except at stage VIII when only 2 p. 100 was recovered.

$17 \alpha$-Hydroxy-20 $\beta$-dihydroprogesterone was identified in several chromatographic systems (see above). The percentages of this steroid tended to increase from the early stages of the cycle up to stage $V$, reaching a maximum of 30 p. 100 . Afterwards, the percentage decreased only slightly (23 p. 100 at stage VIII).

b) C19 steroids. - Androstenedione and testosterone were formed at all stages. The androstenedione/testosterone ratio decreased constantly from stage III a to stage VIII. This decrease corresponded to an apparent stimulation of $17 \beta$-oxydoreductase activity favourizing testosterone production (reduction) (table 5).

TABLE 5

Androstenedione/testosterone ratio at different stages of the cycle (precursor : progesterone)

\begin{tabular}{cccccccc}
\hline \multicolumn{10}{c}{ Stage } \\
\hline I & II & III a & III b & IV & V & VI-VII & VIII \\
\hline 2.89 & 1.43 & 6.20 & 4.00 & 2.50 & 1.25 & 0.50 & 0.25 \\
\hline
\end{tabular}

$11 \beta$-Hydroxyandrostenedione was synthesized at stages I and II, while $11 \beta$-hydroxytestosterone was not formed until stage VIII. Adrenosterone production was not stable in our experimental conditions, only appearing at stages I, II and VI-VIII. At stage VIII, most of the radioactivity (30 p. 100) was recovered in a derivative identified as 11 -ketotestosterone; its synthesis was not detected at earlier stages. 
4) In vitro metabolism of $17 \alpha$-hydroxyprogesterone (table 6).

a) C21 steroids. - More $17 \alpha$-hydroxy-20 $\beta$-dihydroprogesterone was produced from $17 \alpha$-hydroxyprogesterone rather than from progesterone. The percentage of radioactivity recovered in this derivative varied considerably with the stage. The highest percentages were observed at stage I (34 p. 100), stage III a (49 p. 100), and especially at stage V (82 p. 100) when the steroidogenesis was almost completely devoted to the synthesis of this derivative (less than 14 p. 100 of C19 steroids were formed). Traces of cortisol were found at stages VI-VII.

\section{TABLE 6}

In vitro metabolism of $17 \alpha$-hydroxyprogesterone (in p. 100 of the whole of the derivatives)

\begin{tabular}{|c|c|c|c|c|c|c|c|}
\hline \multirow{2}{*}{ Derivative } & \multicolumn{7}{|c|}{ Stage } \\
\hline & I & II & III a & III b & IV & V & VI-VII \\
\hline 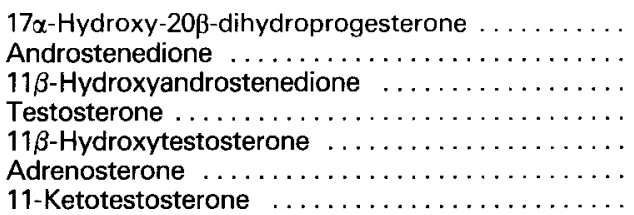 & $\begin{array}{r}34 \\
10 \\
20 \\
6 \\
2 \\
5 \\
<1\end{array}$ & $\begin{array}{r}16 \\
6 \\
32 \\
8 \\
13 \\
11 \\
<1\end{array}$ & $\begin{array}{r}49 \\
7 \\
22 \\
4 \\
4 \\
<1 \\
6\end{array}$ & $\begin{array}{r}13 \\
5 \\
32 \\
6 \\
7 \\
\quad 1 \\
24\end{array}$ & $\begin{array}{l}22 \\
10 \\
34 \\
2,5 \\
7 \\
1 \\
17\end{array}$ & $\begin{array}{r}82 \\
<1 \\
3 \\
2 \\
2,5 \\
<1 \\
6\end{array}$ & $\begin{array}{r}48 \\
1 \\
6 \\
11 \\
13 \\
<1 \\
17\end{array}$ \\
\hline
\end{tabular}

b) C19 steroids. - Due to the fact that $17 \alpha$-hydroxyprogesterone is situated at the "crossroad" of steroidogenesis, the total amount of C19 derivatives recovered was inversely proportional to the amount of $\mathrm{C} 21$ steroids. The synthesis of one or the other of these steroid types thus predominated at a given stage.

At all stages, the « androgen " fraction included androstenedione (only traces at stage $V$ ), testosterone, $11 \beta$-hydroxyandrostenedione and $11 \beta$-hydroxytestosterone. Adrenosterone was produced at stages I, II and IV. 11-Ketostestosterone was not formed at stages I and II but it represented 6 to 24 p. 100 of the radioactivity at stages III to VI-VII.

Overall C19 steroid production predominated over (stages II, III b, IV) or was equivalent to (stages I, III a, VI-VII) the synthesis of $17 \alpha$-hydroxy-20 $\beta$-dihydroprogesterone, except at stage $V$ when there was a massive production of this $C 21$ steroid.

\section{Discussion and conclusions.}

Several works have been carried out on the in vitro steroidogenic metabolism of rainbow trout testis (Arai and Tamaoki, 1967 ; Suzuki and Tamaoki, 1972 ; Kime, 1979). The only data on changes in steroid production during the cycle have been obtained from plasma assays, and those assays included only a small 
number of steroids (Billard et al., 1978 ; Scott et al., 1980). Considerable changes in the gonadosomatic index during the cycle complicate assessment of the physiological significance of the observed variations. Moreover, it is difficult to extract from these data any exact information on the nature of the steroids acting locally in the gonad. If study of the relative percentages of the different metabolites synthesized from a precursor in vitro cannot reflect the global production by the whole testis, it gives information about the orientation of steroidogenic metabolism in the gonad.

Pregnane 5-reduction activity has been reported in the ovary (Reinboth et al., 1966), hermaphroditic gonad (Reinboth, 1978) and testis (Tesone and Charreau, 1980 ) of some teleosts. In our incubations, more $5 \alpha(\beta)$-pregnane-3,20 dione was synthesized at early stages (I to III b) than later. However, this decrease in apparent progesterone reduction coincided with an increase in $17 \alpha$-hydroxylase activity and C19 steroid synthesis. As in mammals (Lerner and Eckstein, 1976) progesterone 5-reduction could be one of the mechanisms regulating testicular androgen production.

The formation of $17 \alpha$-hydroxy-20 $\beta$-dihydroprogesterone has already been reported in incubations of trout testis (Arai and Tamaoki, 1967). The assays carried out by Campbell et al. (1980), on the plasma of spermiating animals, do not show very high concentrations (less than $9 \mathrm{ng} / \mathrm{ml}$ ) contrary to the values found in females $(480 \mathrm{ng} / \mathrm{ml})$. In vitro, great amounts of $17 \alpha$-hydroxy-20 $\beta$ dihydroprogesterone were synthesized at four stages (I, II, V, VI-VII) of the cycle and, at stage $V$, the synthesis of this steroid predominated over C19 steroid synthesis. This may be due either to increased $20 \beta$-oxydoreductase reductive activity or to lowered 17-20 desmolase activity. In fact, an inhibition of this latter activity alone cannot explain this high synthesis since both activities can be increased simultaneously at stages of high androgenic production.

A control of 20ß-oxydoreductase and 17-20 desmolase activities may be hypothesized. During the cycle, this control could favourize the production of $17 \alpha$-hydroxy-20ß-dihydroprogesterone or that of $\mathrm{C} 19$ steroids by orienting the metabolism towards one or the other. At high doses in the rat, HCG inhibits 17-20 desmolase activity (Cigorraga et al., 1978).

$17 \beta$-Oxydoreductase activity, insuring androstenedione-testosterone interconversion, may be another site of the regulation of steroidogenic metabolism. In incubations carried out in the presence of progesterone, the androstenedione/testosterone ratio decreased regularly from stage III a to the end of the cycle, a period when androgenic production as well as plasma gonadotropin concentrations increase (Billard et al., 1978). In a study on the female rainbow trout, we showed that salmon gonadotropin stimulated 17 $\beta$-oxydoreductase activity in favour of testosterone production in the incubated perifused ovary (Sire and Dépêche, 1981).

Taking into account all these data, we propose 4 putative sites which may be involved in the control of steroidogenic metabolism in the rainbow trout testis during the annual cycle (fig. 1).

Gonadotropic control of the enzymatic activities responsible for the cleavage of the lateral cholesterol chain, a well-known process in mammals (Hall, 1970), has 
not yet been studied in fish where the mechanisms of pregnenolone formation have not been elucidated.

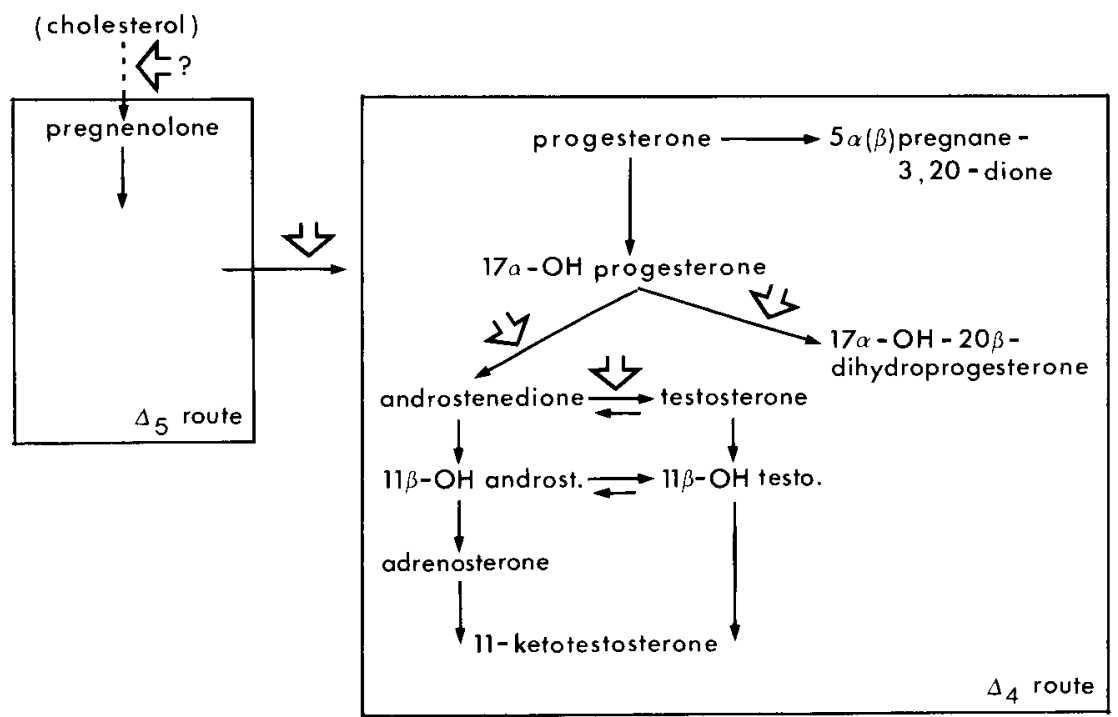

FIG. 1. - Simplified diagram of the routes of major steroid biosynthesis in the rainbow trout testis. Open arrows show the putative sites of metabolic regulation.

The regulation of enzymatic activities involved in the passage from the $\Delta_{5}$ route of synthesis to that of $\Delta_{4}$ is suggested by work on the rainbow trout showing that $\Delta_{5}-3 \beta$-hydroxysteroid dehydrogenase activity is stimulated during the cycle (van den Hurk et al., 1978) or by studies on other species using gonadotropic stimulation of intact (Satyanarayana Rao and Nadkarni, 1978) or hypophysectomized (Pickford et al., 1972) animals.

From our results, it seems that three other steps are modulated: 17-20 desmolase activity, $20 \beta$-oxydoreductase activity and $17 \beta$-oxydoreductase activity.

In our incubation, the synthesis of $17 \alpha$-hydroxy-20 $\beta$-dihydroprogesterone predominated at stages I and III a, when gonial mitotic activity is observed, and at stage $\mathrm{V}$, corresponding to the period at the end of spermatogenesis, that is the time when the spermatocytes in a large number of cysts resume meiosis and divide.

$17 \alpha$-Hydroxy-20 $\beta$-dihydroprogesterone is considered as the inductor of oocyte maturation in several teleost species (Fostier et al., 1973 ; Jalabert, 1976 ; Duffey and Goetz, 1980). This steroid, produced by the ovarian follicle (Fostier et al., 1981), would act on post-transcriptional processes controlling the mechanisms of germinal vesicle breakdown and the resumption of meiosis (Jalabert, 1976). Spermatogenesis does not include phenomena strictly identical to oocyte maturation. However some cellular mechanisms common to both germinal lines are involved in the mitotic activity of the spermatogonia and the meiotic evolution 
of the spermatocytes. As a working hypothesis, we suggest that $17 \alpha$-hydroxy-20 $\beta$ dihydroprogesterone in the male may act upon some step of the mitotic cycle and meiotic processes of the male germ cells.

In the female, a possible role for $17 \alpha$-hydroxy-20 $\beta$-dihydroprogesterone in feedback on the hypothalamo-pituitary system has been suggested. Weil (1981) indicates that $\mathrm{LH}-\mathrm{RH}$ sensitivity could depend on the plasma progesterone level or on a " certain oestradiol/ $17 \alpha$-hydroxy-20 $\beta$-dihydroprogesterone ratio ". The plasmatic content of this steroid is low in males during spermiation (Campbell et al., 1980), a time when the testicular potential for synthesis is relatively high. This would be a point in favour of an intratesticular site of steroid action. More research is needed to test the various hypotheses proposed.

\section{Communication présentée au colloque}

sur la "Sexualisation chez les Vertébrés inférieurs",

Banyuls-sur-Mer, France, avril 1981.

Reçu en juillet 1981

Accepté en novembre 1981.

Acknowledgements. - We wish to thank Dr. R. Billard and Professor R. Ozon for their advice and material help and Mrs. C. Thibier, Miss O. Mulner and Mr. D. Marie for their kind assistance. This work was a part of a research program supported by the DGRST (Aid $n^{\circ} 807$ 0344).

Résumé. Des fragments de testicule de truite arc-en-ciel ont été prélevés aux 8 stades de la spermatogenèse et incubés en présence de progestérone ou de $17 \alpha$-hydroxyprogestérone tritiée. Le spectre des activités enzymatiques potentielles de la voie $\Delta_{4}$ de synthèse conduisant à des métabolites majeurs a été établi pour chaque stade.

1) Une 5-réductase convertit la progestérone en $5 \alpha(\beta)$-prégnane 3,20-dione.

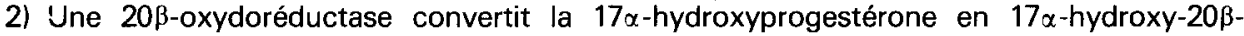
dihydroprogestérone. Son activité est élevée et, à certains stades, la production de ce dérivé égale ou excède celle des androgènes.

3) Certaines activités enzymatiques semblent impliquées dans le contrôle et la modulation du métabolisme stéroïdogène au cours du cycle : 20 -oxydoréductase, 17-20 desmolase, $17 \beta$-oxydoréductase.

4) Le rôle physiologique possible des différents stéroïdes majeurs est discuté : I'hypothèse d'une participation de la $17 \alpha$-hydroxy-20ß-dihydroprogestérone au contrôle de l'activité mitotique des gonies et des spermatocytes et (ou) au rétrocontrôle de l'axe hypothalamohypophysaire est examinée.

\section{References}

ARAI R., TAMAOKI B. I., 1967. Steroid biosynthesis in vitro by testes of rainbow trout, Salmo gairdneri. Gen. comp. Endocrinol., 8, 305-313.

BILLARD R., JALABERT B., BRETON B., 1972. Les cellules de Sertoli des Poissons Téléostéens. I. Etude ultrastructurale. Ann. Biol, anim. Bioch. Biophys., 12, 19-32.

BILLARD R., ESCAFFRE A. M., 1975. Identification des stades de la spermatogenèse de la truite fario d'après la morphologie des gonades et la spermiation. Bull. fr. Piscicult., 47, 111-113.

BILLARD R., BRETON B., FOSTIER A., JALABERT B., WEIL C., 1978. Endocrine control of the teleost reproductive cycle and its relation to external factors : salmonid and cyprinid models. In : GAILLARD P. J., BOER H. H., Comparative endocrinology, Elsevier North-Holland Biomed. Press, Amsterdam.

CAMPBELL C. M., FOSTIER A., JALABERT B., TRUSCOTT B., 1980. Identification and quanti- 
fication of steroids in the serum of rainbow trout during spermiation and oocyte maturation. $J$. Endocrinol., 85, 371-378.

CIGORRAGA S. B., DUFAU M. L., CATT K. J., 1978. Regulation of luteinizing hormone receptors and steroidogenesis in gonadotropin-desensitized Leydig cells. J. biol. Chem., 253, 4297-4304.

DRANCE M. G., HOLLENBERG M. J., SMITH M., WYLIE V., 1976. Histological changes in trout testis induced by injections of salmon pituitary gonadotropin. Canad. J. Zool., 54, 1285-1293.

DUFFEY R. J., GOETZ F. W., 1980 . The in vitro effects of $17 \alpha$-hydroxy-20 $\beta$-dihydroprogesterone on germinal vesicle breakdown in brook trout (Salvelinus fontinalis) oocyte. Gen. comp. Endocrinol., 41, 563-565.

EAGLE H., 1959. Amino acid metabolism in mammalian cell cultures. Science, 130, 432-437.

FOSTIER A., JALABERT B., TERQUI M., 1973. Action prédominante d'un dérivé hydroxylé de la progestérone sur la maturation in vitro des ovocytes de la truite arc-en-ciel Salmo gairdneri. C. R. Acad. Sci. Paris, Sér. D, 277, 421-424.

FOSTIER A., JALABERT B., CAMPBELL C., TERQUI M., BRETON B., 1981. Cinétique de libération in vitro de $17 \alpha$-hydroxy-20 $\beta$-dihydroprogestérone par des follicules de truite arc-enciel, Salmo gairdneri. C. R. Acad. Sci. Paris, Serr. D, 292, 777-780.

HALL P. F., 1970. Endocrinology of the testis. In JOHNSON A. D., GOMES W. R., VAN DE MARK N. L., The testis, vol. 2, Acad. Press, New York.

JALABERT B., 1976. In vitro oocyte maturation and ovulation in rainbow trout (Sa/mo gairdnern), northern pike (Esox lucius), and goldfish (Carassius auratus). J. Fish. Res, Bd Canada, 33, 974988.

JALABERT B., BRY C., BRETON B., CAMPBELL C., 1976. Action de la $17 \alpha$-hydroxy-20 $\beta$-dihydroprogestérone sur la maturation et l'ovulation in vivo et sur le niveau d'hormone gonadotrope plasmatique t-GTH chez la truite arc-en-ciel, Salmo gairdneri. C. R. Acad. Sci. Paris, Sér. D, 283, 1205-1208.

JALABERT B., GOETZ F. W., BRETON B., FOSTIER A., DONALDSON E. M., 1978. Precocious induction of oocyte maturation and ovulation in coho salmon, Oncorhynchus kisutch. J. Fish. Res. Bd Canada, 35, 1423-1429.

KATZ Y., ECKSTEIN B., 1974. Changes in steroid concentrations in blood of female Tilapia aurea (Teleostei, Cichlidae) during initiation of spawning. Endocrinology, 95, 963-967.

KIME D. E., 1979. Comparative aspects of testicular androgen biosynthesis in nonmammalian vertebrates. In DELRIO G., BRACHET J., Steroids and their mechanism of action in nonmammalian vertebrates, Raven Press, New York.

KIME D. E., 1980. The effect of temperature on the testicular steroidogenic enzymes of the rainbow trout, Salmo gairdneri. Gen. comp. Endocrinol., 39, 290-296.

LERNER N., ECKSTEIN B., 1976. Identification of two $5 \alpha$-reduced pregnanes as major metabolites of progesterone is immature rat ovaries (100 × g supernatant) in vitro. Endocrinologv, 98, 179188.

OZON R., 1972. Androgens in fishes, amphibians, reptiles and birds. In IDLER D. R., Steroids in nonmammalian vertebrates, Acad. Press, New York and London.

PICKFORD G. E., LOFTS B., BARA G., ATZ J. W., 1972. Testis stimulation in hypophysectomized make killifish, Fundulus heteroclitus, treated with mammalian growth hormone and/or luteinizing hormone. Biol. Reprod., 7, 370-386.

REINBOTH R., 1978. On steroidogenic pathways in ambisexual fishes. In : Hormonal steroids in fish, Proc. ind. nat. Sci. Acad. (sous presse) et Satellite Symp. on hormonal steroids in fish, Nov. 1978, Delhi (Abstr.).

REINBOTH R., CALLARD I. P., LEATHEM J. H., 1966. In vitro steroid synthesis by the ovaries of the teleost fish, Centropristes striatus (L.). Gen. comp. Endocrinol., 7, 326-328.

SATYANARAYANA RAO G. R., NADKARNI V. B., 1978. The effect of gonadotropins on the steroidogenic potential and spermatogenesis in the testes of the catfish, Clarias batrachus (Linn.). Satellite Symp. on hormonal steroids in fish, Nov. 1978, Delhi (Abstr.).

SCHMIDT P. J., IDLER D. R., 1962. Steroid hormones in the plasma of salmon at various stages of maturation. Gen. comp. Endocrinol., 2, 204-214.

SCOTT A. P., BYE V. J., BAYNES S. M., SPRINGATE J. R. C., 1980. Seasonal variations in plasma concentrations of 11-ketotestosterone and testosterone in male rainbow trout, Salmo gairdneri Richardson. J. Fish Biol., 17, 495-505. 
SIRE O., DEPECHE J., 1981. In vitro effect of a fish gonadotropin on aromatase and 17 $\beta$-hydroxysteroid dehydrogenase activities in the ovary of the rainbow trout (Salmo gairdneri Rich.). Reprod. Nutr. Develop., 21, 715-726.

SUZUKI K., TAMAOKI B. I., 1972. Intracellular distribution and substrate specificity of steroid $11 \beta$-hydroxylase in testes of rainbow trout (Salmo gairdner). Gen. comp. Endocrinol., 18, 319-328.

TESONE M., CHARREAU E. H., 1980. Steroid biosynthesis in the gonads of the teleost fish, Jenynsia lineata. Comp. Biochem. Physiol., 65 B, 631-637.

VAN DEN HURK R., PEUTE J., VERMEIJ J. A. J., 1978. Morphological and enzyme cytochemical aspects of the testis and vas deferens of the rainbow trout, Salmo gairdneri. Cell Tissue Res., 186, 309-325.

WEIL C., 1981. La fonction gonadotrope de l'hypophyse au cours du cycle sexue/ chez deux poissons Téléostéens, la carpe commune (Cyprinus carpio) et la truite arc-en-ciel (Salmo gairdneri), son controle par l'hypothalamus, les gonades et les facteurs externes. Th. Doct. Etat, Paris. 